\title{
Budget tackles social determinants of health
}

$\mathrm{T}$ he federal Liberal government's inaugural budget made major investments in tackling the social determinants of health but allocated relatively little to new health spending in a \$294-billion plan focused on improving the lives of Indigenous Canadians and the middle class.

The budget document, Growing The Middle Class, detailed an unprecedented investment of $\$ 8.4$ billion over five years in housing, education and child welfare for Indigenous peoples, and \$2 billion to end longstanding boil-water advisories on reserves.

However, the March 22 budget was light on specific measures to improve health care for most Canadians. It did promise an additional $\$ 290$ million over the next three years to improve immunization coverage, expand the Nutrition North program, support innovations in the health care system, combat cancer and target men's and women's specific health needs.

Despite reiterating Health Minister Dr. Jane Philpott's promise to craft a new Health Accord with the provinces and territories, and the government's intention to re-engage in health care after the previous government's absence, the budget made it clear the Liberals are not yet ready to invest in the overall system.

"We are in the midst of a consultation process ... and Minister Philpott will have more to report on that as she works together with provinces and territories," Morneau told a media conference. The previous Health Accord between the provincial, territorial and federal government ended in 2014.

Canadian Medical Association (CMA) Past-President Dr. Chris Simpson said the government's renewed commitment to a health accord is good news. "Get that organized first, then we can look at homecare and pharmacare and other cross-Canada initiatives. This work is best done in the context of a health accord."

\section{Research and innovation}

The government did, however, trumpet a new innovation agenda designed to propel Canada to the forefront of global research and development. The budget invested $\$ 2.3$ billion over three years in discovery research, genomics, stem cell research, theoretical physics, brain research, agricultural science, and in ensuring Canada's continued partnership with the European Space Agency and participation in the International Space Station. Included in that $\$ 2.3$ billion is an extra $\$ 95$ million per year to the federal granting councils, of which $\$ 30$ million will go to the Canadian Institutes of Health Research. This is the granting councils' highest annual funding increase in over a decade, Morneau said in his budget speech.

In addition to the boost in funding, the government announced it will conduct a comprehensive review of the three granting councils this year.

There was also $\$ 2$ billion over three years allocated to pay half the costs of modernizing Canada's post-secondary research infrastructure, much of which is over 25 years old.

And though the usefulness of Canada Health Infoway has recently been questioned, the budget provides it with $\$ 50$ million over two years for e-prescribing and tele-homecare. Infoway has received $\$ 2.1$ billion in federal funding since 2001.

Other health-research investments include:

- \$237.2 million to Genome Canada to support promising breakthroughs;

- \$39 million over three years to the Canadian Foundation for Healthcare Innovation to support more efficient practices;

- \$32 million over two years (starting in 2017/18) for the not-for-profit Centre for Drug Research and Development to translate discoveries into new medicines and therapies;

- \$12 million over two years to support the Stem Cell Network; and

- up to \$20 million over three years to the Brain Canada Foundation's Canada Brain Research Fund. 


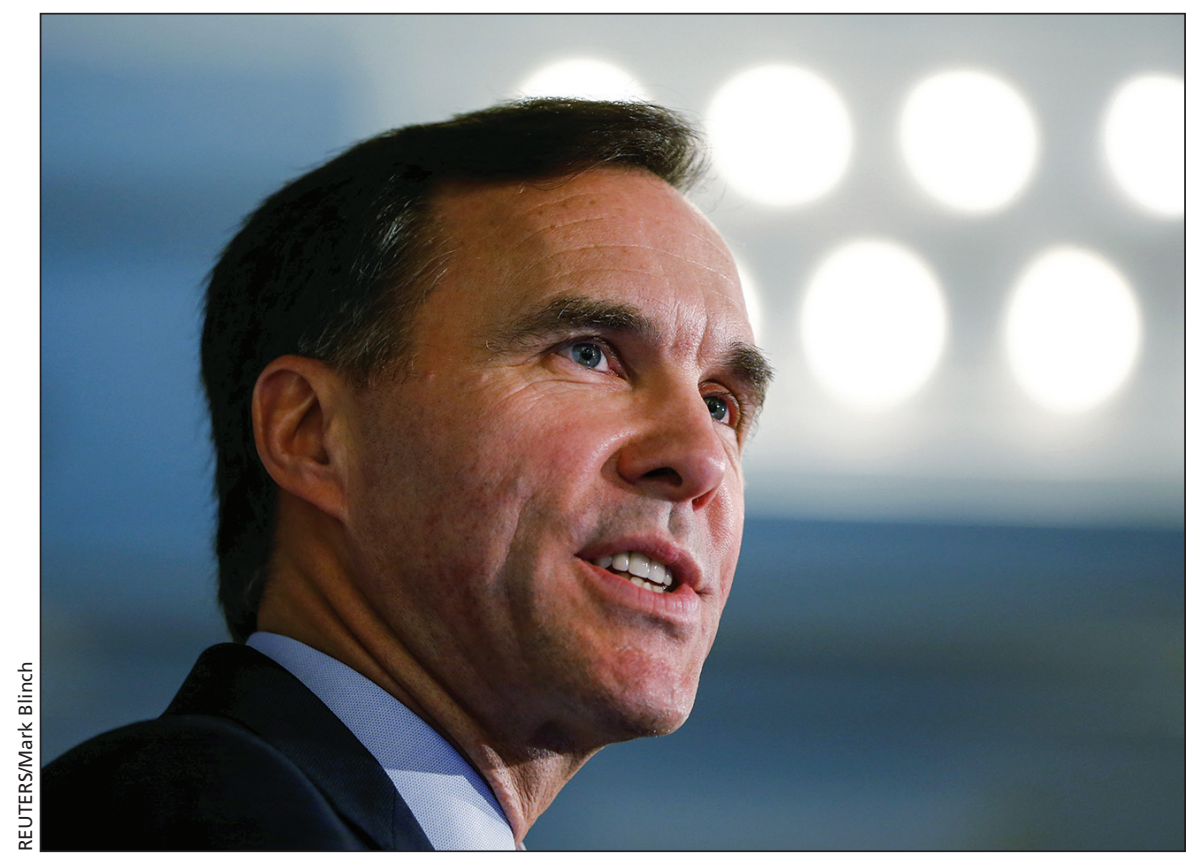

The new Canada Child Benefit is "the most significant social policy innovation in a generation," said Finance Minister Bill Morneau.

\section{Social determinants}

The budget's investments in the social determinants of health include a new Canada Child Benefit, which Morneau called "the most significant social policy innovation in a generation." The benefit increases monthly payments to low- and middle-income families and will no longer be clawed back at tax time. It will, on average, provide almost $\$ 2300$ more a year for eligible families in 2016/17.

"It will lift hundreds of thousands of kids up from poverty," Morneau said in his speech.

The CMA has been "bullheaded about income security, housing, food security and clean water," said Simpson. "These initiatives set the tone for the future."

Prime Minister Justin Trudeau's public support for the need for increased mental health services did not, however, translate into new dollars to improve treatment in those areas. And even the well-publicized suicide crisis in isolated Indigenous communities such as the Pimicikamak Cree Nation in Cross Lake, Manitoba, did not merit any specific measures. Nor were there any investments in direct services to improve the health of Indigenous peoples - the poorest, sickest people in the country.

\section{Indigenous investment}

There was, however, a substantial \$8.4-billion investment in improving the socioeconomic conditions of Indigenous people, including $\$ 2.6$ billion over five years for primary and secondary education on reserves and $\$ 833$ million to repair or build housing. The budget also provided $\$ 29.4$ million for child care, $\$ 10.4$ million to renovate and build shelters for victims of family violence on reserves and $\$ 270$ million over five years to build or renovate nursing stations and residences for health care workers.

A budgeted $\$ 634.8$ million to prevent Indigenous children from coming into the care of child welfare agencies was disappointing, said Cindy Blackstock, executive director of the First Nations Family and Child Caring Society of Canada. "It's about $\$ 40$ million short of what our estimates say is required."

Morneau also pledged to put an end to the "unconscionable crisis of boil-water advisories on reserves" with $\$ 2$ billion for monitoring water quality and improving water and wastewater facilities.

Other health-related spending:

- \$25 million over two years to improve veterans' services, including increasing the Disability Award, expanding access to the Permanent Impairment Allowance and increasing income replacements;

- Increasing the Guaranteed Income Supplement by as much as $\$ 947$ per person annually;

- \$112 million over two years for a homelessness strategy;

- \$65 million over five years for Nutrition North Canada, which subsidizes perishable food, plus $\$ 14$ million per year to expand the program;

- \$38.5 million over two years to bolster services at the Canadian Food Inspection Agency;

- \$25 million over five years to help the Public Health Agency of Canada improve vaccine access and uptake;

- $\$ 5$ million over five years to the Heart and Stroke Foundation to support research on women's heart health; and

\section{There was a substantial \$8.4-billion investment in improving the socioeconomic conditions of Indigenous people.}

- $\$ 4$ million over four years to the Canadian Men's Health Foundation to raise awareness of men's health issues like heart disease, diabetes and alcohol-related deaths.

In all, the new budget allocates $\$ 50.2$ billion in 2016/17 for new projects, adding $\$ 6.7$ billion to the deficit. - Barbara Sibbald and Laura Eggertson, CMAJ

CMAJ 2016. DOI:10.1503/cmaj.109-5258

\section{More News online}

To read more $C M A J$ news articles, visit cmaj.ca/site/home/news.xhtml 